\title{
Affordable Housing Policy: Issues and Challenges among Middle-Income Groups
}

\author{
S. Baqutaya, A. S. Ariffin, and F. Raji, Member, CBEES
}

\begin{abstract}
Shelter is a fundamental human need. Housing plays an important role in people's wellbeing, contributing to the physical and mental health, education, employment and security outcomes for individuals. Still, to date the major challenge is housing issue particularly on the establishment of adequate affordable livable home standards for the nation; and failure to achieve that will lead to a housing stress. For that reason, this study presents a research on issues related to affordable housing among middle-income groups. It examines on how certain issues of housing affordability affect societal well being. The purpose is to present an overview of affordable housing problem and to set out a series of options that should be considered as part of a comprehensive "way in managing these issues". Data was gathered from fifty respondents, using "housing issues questionnaires". The accumulated data were then analyzed; descriptive statistics were used to interpret these issues. The findings indicated that three main housing issues faced by middle-income groups are housing price, housing loan and housing schemes' policy. Hence, it is highly advisable to address these issues to ensure the vast majority of the population are affordable to own livable property and directly may enhance the quality of life in Malaysia.
\end{abstract}

Index Terms-Affordable housing, housing among middle-income group, housing issues, housing policy.

\section{INTRODUCTION}

Affordable housing issues become greater focus of every researcher, managing the growth of housing price and reducing the effects of housing issue is of great potential benefits to every society. Because when housing issues occur in any society it may lead to other social problem. Parrillo stated that housing issue constitute a social problem with various social, economical and cultural implications [1]. As a matter of fact, housing issue is always threatening both low and middle-income households [2]. In these circumstances the housing issue is one of the most disturbing structural and functional social problem, with certain cultural aspect [3], it became a constraint for some middle-income groups, whereas it had previously mainly been an issue for those on lower incomes [4]. Therefore, housing issues need to be considered and necessary actions need to be taken immediately, in Malaysia for instant, according to Zainal Abidin Hashim, affordability issues has never been dealt with in detail and no specific study on housing affordability has been done for the past four years [5].

Thus, the aim of this paper is to identify the actual issue related to the affordable housing. Based on feedback from

Manuscript received November 28, 2014; revised February 28, 2015.

$\mathrm{S}$. Baqutaya is with the University Technology Malaysia, Malaysia (e-mail: shadiya.kl@utm.my). respondents, this study measures different issues namely loan availability, housing affordability, housing scheme's policy, consumer attitude, neighborhoods, housing quality, economic development and transportation issues. However, the focus on this paper is only the first three issues respectively. Therefore, it is hoped that the results and discussion of this paper would help to instill more understanding of the real issue related to housing. Because proper knowledge in identifying the main issue of affordable housing can assist the government and stakeholder to handle and effectively resolve these issues, which might affect the citizen as well as the whole county health.

\section{LITERATURE REVIEW}

Issues relating to home ownership have been a major concern among political leaders, town planners and the government over the years. Owning a house is considered a big issue in today's societies. As such, an exact measure of housing affordability is essential to ensure the need for shelter.

\section{A. Is Housing Affordability an Issue}

Housing is the basic human needs; it is also one of the most important components of urban economy development in any country. In addition, the socioeconomic stability of a country is always depending on the housing affordability of the country. For this reason, housing is a valuable asset that always has a great impact on societal well-being. Nevertheless, what is "housing" for if is not affordable. Indeed, the unaffordable housing is much more common than the-impossible-to-ignore situations. Housing affordability became greater focus in every society; and the affordability problem with regard to housing market is one of the most controversial issues within most developed and developing countries [6]. Several attempts have been made to understand how and why affordability problems are created. What does affordable housing mean in this context?

The exact definition of affordable housing is a very complex matter, which is the subject of different analyses and continuous debate among experts. Beyond the details of this debate, a general consensus can be reached about a definition of affordable housing, which is centered on the idea of a "households should pay no more than $30 \%$ of their income for housing, including utilities" [7]. Families that pay more, especially middle and lower income families, are considered cost burdened and housing problem because they may have difficulty paying for non-housing needs such as food, clothing, transportation, childcare, and medical care [8].

Indeed, affordability problems for middle-income 
households in Malaysia are widespread in most major cities and towns in Malaysia where many of them find it difficult to purchase a home [9]. Therefore, policy maker and relevant agencies need to take an action to solve this issue.

\section{B. Is Housing Scheme's Policy an Issue in Malaysia}

To answer this question, we need firstly to highlight that housing policy in Malaysia has evolved over the years through the number of national development plans. Housing programs implementing the policy are subject to some administrative regulations as the one applied to land policy. The objective of the policy is to provide affordable and adequate housing to the low-income group only. However, the main issue is why affordable housing is not being provided to middle-income households (MIH). Essentially, in the Tenth Malaysia Plan (10MP) [10], the government focused on building houses in a suitable location and more conducive environment for low-income groups. However, many households may not be covered by the housing assistance program, because there are many people who stuck in the middle-income trap, they are not qualify for low-cost housing and yet, cannot afford to buy even the "medium cost" residential projects. The middle-income groups, which consist of $40 \%$ percent of Malaysia population, were left on their own to face the challenge in getting their own house [11]

In spite of that, it was evident that little research has addressed the affordability problem faced by the middle-income households, housing issue and housing policy need to be addressed widely as an important issue face by the citizen.

\section{The Housing Loan's Issue in Malaysia}

Housing loan is one of the core issue faced by the Malaysian citizen. This issue occurs due to dealing with extreme housing price, high interest rate, low-income increment, and price inflation of living goods. According to Goh that high value of house price had actually, make buyers delayed to own a house, or forced them to consider other than their preference, or suffering with high housing loan [12]. In the Malaysia Property News, the property bubble in Malaysia is formed when there is excessive bank-lending and low borrowing cost leading to investment as well as plenty of speculation. Property prices will increase until they reach unsustainable levels relative to incomes and other economic elements. Banks will be short on capital, while cases of non-performing loans start to show up. When banks start cutting back credit, it will in turn affect the economy, as the move will affect the price of property as well [13]. Based on this evidence, loan issue need to be studied.

\section{Methodology}

Simple random sampling was used to conduct the survey that measures housing issues. The questionnaire was distributed to a large number of potential participants from different areas in Kuala Lumpur. Finally, 50 responses were only evaluated from those of middle-income group respondents.

\section{FINDING AND RESULTS}

The scale used on this study focuses on different housing issues, and the focus on this paper is only on housing price, housing loan and housing scheme policy. Frequency was conducted to calculate the number and percentage of respondents' answer to all questions. The results were highlighted as followed:

\section{A. Best Housing Price}

The first issue measured in this study was on housing price; the housing bubble and/or the extreme increase in the price of the houses is considered the main issue faced by the middle-income group in Malaysia, and the result was highlighted in Fig. 1:

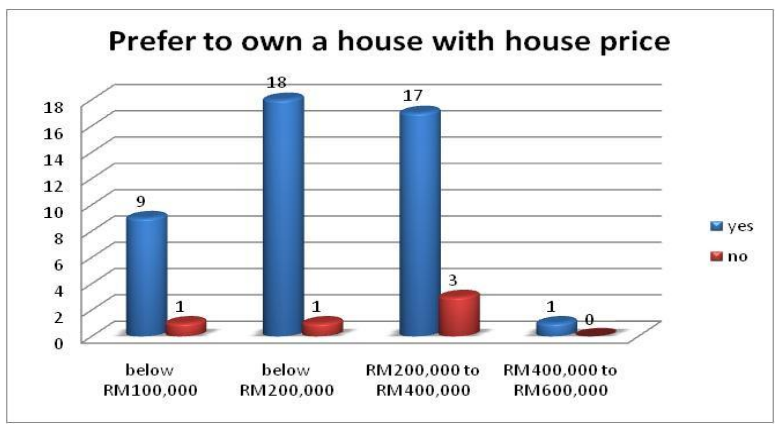

Fig. 1. Prefer to own a house with the respective housing price.

The above Fig. 1 indicated that large number of participants $(90 \%)$ likes to have their own house, in spite of that affordable housing price to $58 \%$ per cent of them is below RM200,000, while $40 \%$ per cent of them is between RM200,000 to RM400,000, and the other 2\% is RM400,000 to RM600,000. This outcome showed that housing price is one of the main issues among middle-income group in Malaysia. But where to get a house below RM200,000 these days. According to Deputy Finance Minister, Datuk Donald Lim Siang Chai, the property price is expected to rise $10 \%$ per cent to $20 \%$ per cent in the coming years [14]. The National Property Information Centre (NAPIC) found that the residential property in all house price index rise in about RM8.9 billion to RM14.7 billion for the year 2010 [15]. This issue is very crucial and needs to be addressed very fast; therefore, the government, planner, industries, policymakers need to work together in reviewing the existing policies and establishing appropriate programs that help the nations to have their own house with reasonable price.

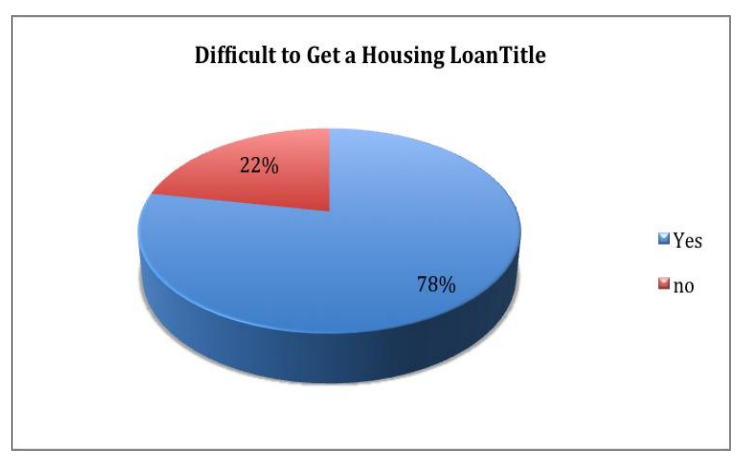

Fig. 2. Difficult to get a housing loan. 


\section{B. Difficult to Get Housing Loan}

Based on the current study, the other important issue faced by the middle-income group is loan availability and stricter lending guidelines. It was indicated that it is difficult to get housing loan in Malaysia due to the stricter lending guidelines; therefore, respondents highlighted this difficulty in the Fig. 2.

The above Fig. 2 indicated that $78 \%$ per cent of the respondents were agreed with difficult to obtain housing loan, and only $22 \%$ per cent of them were disagree with that assumption. This finding is slightly different from the finding of Zairul, according to him Malaysia recorded as one of the highest household debt in the world; half of the household incomes are used to pay monthly debt [16]. Indeed, if Malaysia is the highest household debt meaning they are easily giving loan to their citizen, and is not difficult as found in this study. Yet, Dato' Abdul Rahman Dahlan, indicated that since January 1, 2012, Bank Negara Malaysia has implemented stricter lending guidelines. Mortgage eligibility assessment will be based on net income, considering statutory deductions for tax, Employees Provident Fund (EPF) contributions and all other debt obligations [17]. And recently the same bank announced a new regulation that property buyers will no longer have the option to take housing loans for longer than 35 years and personal loans for a period of up to 10 years only [18]. All these shows the strict process and procedure that citizen need to go for in order to buy a house, and some of these rules makes difficult for young people to get a step on the housing ladder. Therefore, policy makers must be aware of people's need, they should make housing loan process easier for the nation, so that people can buy house and enjoy healthy living slandered.

\section{The Important of Revising Housing Schemes Policy}

One more issue faced by the middle-income group is the housing policy schemes that is only focusing on the low-income group and ignoring the middle-income group. Unfortunately, millions of middle-income families across the nation are hopeless, they are not qualify for low-cost housing and yet, cannot afford to buy even the "medium cost" residential projects. As in the objective of this study the middle-income group were investigated and their views on the important of revising housing scheme's policy were highlighted. The result was explained as followed in Fig. 3:

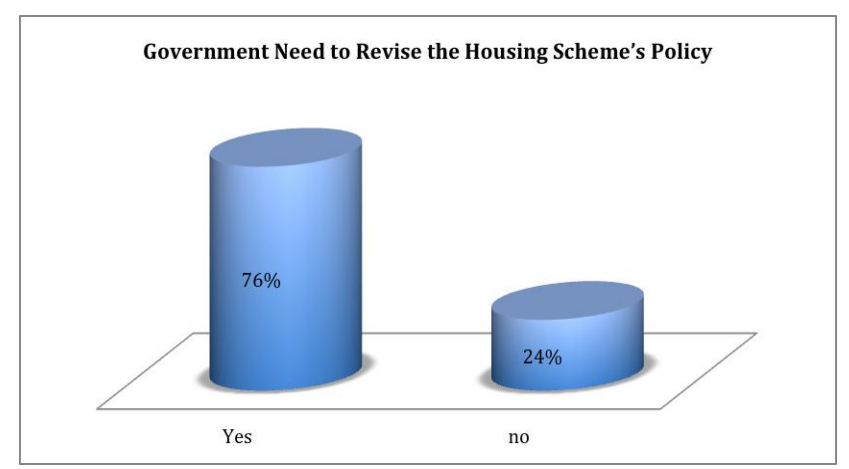

Fig. 3. Government need to revise the housing scheme's policy.

The Fig. 3 indicated that the majority $76 \%$ per cent of the respondents agrees with the importance of revising the housing scheme's policy, as it was previously focusing on providing affordable and adequate housing to the low-income group only. Therefore, government must present new housing policy that is aiming at providing affordable housing not only for low-income people but also most importantly, the middle-income households (MIH).

\section{DISCUSSION AND CONCLUSION}

The Although much remains to be learned, the current research offers strong support for the view that the middle-income group are almost the large group that are trapped in the affordable housing issues. The challenge is how to help them overcome all the issues that is related to affordable housing. There is no doubt that the findings of this study have a number of implications that require attention in eliminating or reducing housing issues among them. As people involve in different types of issues and challenges so also do middle-income group in different countries; therefore, a number of mitigation measures may be considered.

Housing issues, often occur worldwide; affect the thinking of people, as it is one of the basic needs of human being. The objective of this study was to analyze issues related to affordable housing among middle-income group. Eventually, researcher investigated the exact issues as mentioned by the respondent. The results clearly indicate the following: 1) Housing prices continue to rise; 2) housing loan getting more strict; 3) less choices are available for middle-income groups as they found it difficult to own a house at the location they like; 4) the housing scheme policy that need to be revised. Based on this finding, researcher is suggesting that, Malaysia need to look carefully at these issues, reduces its consequence, and promotes the livelihood of the nations by solving these issues. Furthermore, on a practical level, the contribution of this study lies in the utilization of research data, in order to reduce issues related to affordable housing and adjust the living condition by taking the citizen well being into account.

\section{ACKNOWLEDGMENT}

I would like to acknowledge and extend my heartfelt gratitude to The Ministry of Education and Universiti Teknologi Malaysia for the financial assistance in funding this research. My sincere thank to all my colleagues who kindly provided valuable and helpful comments of this paper.

\section{REFERENCES}

[1] V. N. Parrillo, "Understanding race and ethnic relations," Boston: Allyn and Bacon, 2002.

[2] C. Sheldon, (2007). Homelessness in a growth economy: Canada's 21 st century paradox. A Report for the Sheldon Chumir Foundation for Ethics in Leadership. [Online]. Available: http://www.chumirethicsfoundation.ca/files/pdf/SHELTER.pdf

[3] C. Zamfir, "Situatia saraciei in Romania: Dimensiuni surse grupuri de risc," Poverty in Romania: Dimensions and Groups of Risk in Romania Sociala, 2001-2002.

[4] Housing Affordability: Summary version of final report-March 2012 The New Zealand Productivity Commission. [Online]. Available: http://www.productivity.govt.nz/sites/default/files/Summary\%20Vers ion\%20-\%20Final\%20Housing\%20Affordability\%20Report_0_0.pdf

[5] Z. A. Hashim, "House price and affordability in housing in Malaysia," Akademika, vol. 78, pp. 37-46, 2010.

[6] M. T. Nguyen, "Does affordable housing detrimentally affects property values? A review of the literature," Journal of Planning Literature, vol. 20 , no. 1 , pp. 15-26, 2005. 
[7] W. O’Dell et al., "Weaknesses in current measures of housing needs," Housing and Society, vol. 31, no. 1, pp. 29-40, 2004.

[8] Affordable Housing. (15 May 2012). US Department of Housing and Urban Development. [Online]. Available: http://www.hud.gov/offices/cpd/affordablehousing/

[9] W. N. Azriyati (2013). A study on affordable housing within the middle-income households in the major cities and towns in Malaysia. [Online].

Available: http://www.inspen.gov.my/inspen/v2/wp-content/uploads/2009/08/Af fordable-housing.pdf

[10] Tenth Malaysian plan, Tenth Malaysian Plan, 2011-2015. Percetakan Nasional Berhad, Kuala Lumpur. [Online]. Available: https://www.pmo.gov.my/dokumenattached/speech/files/RMK10_Sp eech.pdf

[11] K. C. Chiali and A. Choon. (2014). People's perception of affordable housing. [Online].

Available: http://www.starproperty.my/index.php/articles/property-news/peoples -perception-of-affordable-housing/

[12] J. Goh. (September 27, 2012). Property prices increase at slower pace. The EDGE. [Online]. Available: http://www.theedgemalaysia.com/in-the-financial-daily/215199-prop erty-prices-increase-at- slower-pace.html

[13] Malaysia Property News, Property market Report, Malaysia: Ministry of Finance, 2010.

[14] S. Zaquan. (04 April 2012). Slower growth in property sector. [Online]. Available:

http://www.theedgeproperty.com/news-a-views/9725-slower-growth-i n-property-sector.pdf

[15] F. N. M. Husain et al., "Housing bubbles assessment in Klang Valley, 2005-2010," PROSIDING PERKEM VI, JILID 1, pp. 561-574, 2011.

[16] M. M. N Zairul, "Housing dilemma among young starters in Malaysia," Elixir Sustain, Arc. 58, pp. 14923-14926, 2013.

[17] Dato' Abdul Rahman Dahlan. (2013). Malaysian Housing and Property Summit. [Online]. Available: http://www.asli.com.my/uploads/20131030115427_KEYNOTE\%20 \%20ADDRESS\%20YBM-16th\%20ASLI\%20Malaysian\%20Housing $\% 20$ and $\% 20$ Property\%20Summit $\% 202013 \% 20 \% 28$ Edited $\% 2026 \mathrm{Au}$ g\%29.pdf

[18] Monthly Statistical Bulletin. (2010). Bank Negara Annual Report. [Online].

Available: http://www.bnm.gov.my/files/publication/ar/en/2010/ar2010_book.p df

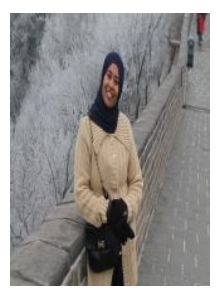

Shadiya Baqutayan is a senior lecturer at University Technology Malaysia. She specialized in counseling and clinical psychology. She is famous in counseling, research writing and publishing paper. She published many journals and attended many conferences in counseling, management, psychology, public health and societal good. She is well known in self-motivating, hardworking, excellent leadership, interpersonal and communication skills. In addition to, public relations, counseling and motivating others. She received different award from different organizations, in 2013 she received from MAKNA the award of best counselor to cancer patients, she also received from Embassy of the Islamic Republic of Iran the award of best lecturer to international students, and from UTM the award of best performance (Citra Karisma).

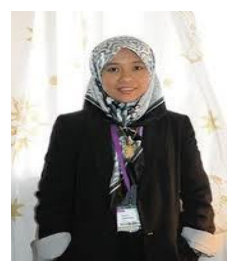

Aini Suzana Ariffin is a senior lecturer at University Technology Malaysia. She is a competent strategist in the area of S\&T policy development that brought high impact on the nation building and economic growth in Malaysia. She earned her $\mathrm{PhD}$ degree in science, technology and innovation policy management from University of Manchester in United Kingdom, master degree in euro-Asia international business from Aix-Marseille Universite' in France and bachelor degree in International Business, University of Miami in Florida, United States of America. Over the past 25 years, she contributed substantially to the development of national policy and strategic development plan such as the 8 Malaysia Plan (2000-2005) and the 9 Malaysia Plan (2005-2010) under the science, technology and innovation chapter and developed more than 5 national policy papers for R\&D and industrial sectors.

She has a proven track record for successful research collaborations both nationally and internationally where she managed to position Malaysia in the international arena by functioning as a deputy secretary general of World Organization of Industrial Technological Research (WAITRO), the focal point for the global research alliances (GRA). In addition she is contributing to the completion of multi-million ringgit worth of mega projects, namely KLCC and KLIA, Advanced Research Centers particularly in supporting government's directives in maximizing the utilization of our natural gas for energy and air-conditioning supply. She served as a judge in various national committee awards such as prime minister's innovation award organized by ministry of science, technology and innovation (MOSTI) and Malaysian brand award organized by ministry of international trade \& industry (MITI) She has been invited to speak in various local and international seminars and conferences.

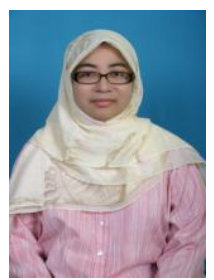

Fauziah Raji is a senior lecturer at University Technology Malaysia. She did her degree on property management (university technology Malaysia), Msc. urban land appraisal (Reading), and $\mathrm{PhD}$ real estate (UTM) She is a member of Malaysian Royal Institute of Surveyors (MRISM) - M4808, probationary valuer with BOVAEA - PV 1498, and Persatuan Tanah Malaysia PERTAMA: Pro-Tem Tresurer. Her area of interest is very broad, she is interested in privatization and private finance initiative (PFI), techniques of valuation especially involving green buildings and intellectual property, development of Waqaf land and Malay Reserve land, sustainability based on the three pillars of environmental, social and economic sustainability, ground water policy, consensus Building, and feminist research. She received different award from different organizations, for instant, excellence award JPPH 1996, excellence award UTM 2002, and excellence award UTM 2012 